\title{
Mr. White en la voz de sus poetas
}

\section{Mario MURGIA}

That iolly shepheard, which there piped, was Poore Colin White (who knowest not Colin White?) He pyped apace, whilest they him daunst about. Pype iolly shepheard, pype thou now apace Vnto thy loue, that made thee low to lout: Thy loue is present there with thee in place, Thy loue is there advaunst to be another Grace.

\section{Edmund Spenser}

\section{The Faerie Queene}

Colin White no tiene tumba. No la tiene ahora ni la tendrá jamás. Su voz resuena en cada lectura, en cada posibilidad de interpretación y en cada juicio sobre algún texto, alguna idea, algún movimiento nuestro en la vida diaria. Tal vez por ello, por la constante presencia de su voz, esta nota ha resultado en principio tan esquiva; porque la estatura de Mr. White, al menos desde la prosa, es punto menos que inconmensurable.

¿Para qué contar más anécdotas? Basta parar oreja por los pasillos de la Facultad para oírlas todas, algunas más ciertas que otras. ¿Para qué enumerar las cosas que aprendimos de él? Resultan evidentes en nuestros procederes, en los asuntos que nos interesan, académicos o no. ¿Para qué intentar describir otra vez el dolor, la orfandad, que nos causa su partida? Ya se han agotado los adjetivos en el transcurso de las últimas semanas.

Así, seco de palabras, prefiero dejar que los poetas hablen, como sólo ellos han podido hacerlo, de Mr. White, con quien siempre sostuvieron diálogos intensos, inteligentes, improbables. (Al pensar en versos, los adjetivos vuelven de forma irremediable, transformados, encarnados en la fuerza que Mr. White admiraba tanto de la "buena poesía”, como el mismo la calificaba.)

Keats tiene, por su cercanía a él, la voz cantante en cuanto a la personificación de nuestro profesor. A través de la figura de Wordsworth lo ha hecho amigo de los sabios y maestro de lo bueno, con un sentido común afín a las canciones proféticas que el poeta escucha y lee en su propio tiempo. Keats, como muchos de nosotros, ha visto así a Mr. White en el coro de los hombres inmortales. Él niega la posibilidad de olvido, al 
menos en el sentido de la influencia, para un personaje que, como su propio ruiseñor, no ha nacido para la muerte, sino que determina a generaciones hambrientas de poesía y cálida razón. Tal es el Colin White que concibe Keats en su oda al ruiseñor, aturdido por su viaje entre el sueño y la vigilia.

En versos quizá técnicamente más admirables que los de Keats, Tennyson (en cuya perfección lírica Mr. White encontraba, sin embargo, motivo de sospecha) transforma su voz en la de Melpómene y se declara indigno de pronunciar los perennes misterios de un hombre amado que, tres veces grande y desde la cubierta de un barco, se inclina para saludarnos. Tennyson confunde su amor por Arthur Hallam con la admiración a nuestro maestro al convertirlo en numen de su avasallador In Memoriam.

Con tono más mundano, en referencia a su vida militar en una Corea disfrazada de India y con el nombre de un bhisti de regimiento, el conforme soldado que fuera $\mathrm{Mr}$. White en su juventud se ve de pronto ensalzado por Rudyard Kipling: el narrador y poeta admite que el maestro es un hombre mejor que él al rebautizarlo Gunga Din. La humildad, la nobleza y la sapiencia de Colin White conmueven a Kipling. Inevitablemente los poetas ingleses agolpan sus voces para hablar del maestro: Pope también aparece y, al hacerse oír, compara al profesor con una vid generosa, mientras que Marvell, mediante el grito de una ninfa, anuncia en medio de sus jardines que llorará con lágrimas pétreas su partida.

Y no obstante, no son sólo los poetas que comparten la lengua y la tierra de Mr. White quienes hablan de él con vehemencia. También en español -idioma de imposibles subjuntivos y géneros intercambiables para la mente inglesa- se componen versos para el maestro. Desde la Veracruz que dejó pasar a Mr. White a tierras mexicanas, Salvador Díaz Mirón dice pensando en él y en sus lecturas que la poesía canta historia, pero también vaticina, desde hace ya más de un siglo, que quienes escribimos ahora, en la circunstancia de su ausencia, encontraremos las cuartillas de papel en blanco con visos de lápidas sin letras.

Pero a pesar del dolor de la muerte, cantado ya por Díaz Mirón, propongo a los poetas y a ustedes, los lectores, que como lo pidió el mismo Mr. White alguna vez, no nos lamentemos más por haber levado él sus anclas. No lo lloremos, como reza alguna canción de la Inglaterra medieval, durante doce meses y un día más. Ante él, pareceríamos ridículos. Dejemos, por el contrario y como sugiere W. H. Auden, que termine de enseñarnos, como al hombre libre, a celebrar. Celebremos entonces con pasión y con el más común de los sentidos: ipensemos, pues! 